\title{
Quality characteristics of Tenebrio molitor L. ingested yuzu supplemented feed
}

\author{
Sang-Jun Park ${ }^{1}$, Ji-Hoon $\mathrm{Na}^{1}$, Chul-Gyo Lee ${ }^{1}$, Jae-Hee Jeong ${ }^{1}$, Cheol-Min Kim ${ }^{1}$, \\ Hong-Bi Han ${ }^{1}$, Bok-Seon Kim ${ }^{1}$, Chang-Hee Park ${ }^{2}$, Chang-Ki Huh ${ }^{1 *}$ \\ ${ }^{1}$ Department of Food Science and Technology, Sunchon National University, Suncheon 57922, Korea \\ ${ }^{2}$ Team of High Technology Farm, Goheung Agricultural Technology \& Extension Center, Goheung 59549, Korea
}

\section{유자 첨가 사료보충제 식이 갈색거저리의 품질 특성}

\author{
박상준 $^{1} \cdot$ 나지훈 $^{1} \cdot$ 이철교 $^{1} \cdot$ 정재희 $^{1} \cdot$ 김철민 $^{1} \cdot$ 한홍비 $^{1} \cdot$ 김복선 $^{1} \cdot$ 박창희 $^{2} \cdot$ 허창기 $^{1 *}$ \\ ${ }^{1}$ 순천대학교 식품공학과, ${ }^{2}$ 고흥군농업기술센터
}

\begin{abstract}
In this study, we examined the quality of Tenebrio molitor L. that ingested yuzu supplemented feed at four feed compositions: C120 (120 g Chinese cabbage), C80+Y40 (80 g Chinese cabbage+40 g yuzu peel), C40+Y80 (40 $\mathrm{g}$ Chinese cabbage $+80 \mathrm{~g}$ yиzu peel) and Y120 (120 g yuzu peel). Tenebrio molitor $\mathrm{L}$. was fed for $90 \mathrm{~d}$ at a rate according to age, after which the moisture, crude protein, crude fat, and crude ash contents of the samples were determined to be $\mathbf{0 . 4 9 - 0 . 5 0 \%}, \mathbf{5 2 . 5 8 - 5 3 . 9 0 \% , 3 0 . 7 6 - 3 2 . 3 4 \%}$, and $3.32-3.45 \%$, respectively. Color values, namely yellowness (b) and redness (a), were observed to decrease with increasing yuzu ingestion, and the C80+Y40 sample exhibited the highest lightness $(\mathrm{L}=36.28)$. The $\mathrm{K}$ and Mg contents were observed to increase with increasing $y u z u$ content, and $\mathrm{Pb}$ and As were not detected in any Tenebrio molitor $\mathrm{L}$. sample that ingested the yuzu supplemented feed. The free amino acid (serine and alanine) contents also increased with increasing yuzu content, while the histidine and arginine contents were observed to decrease with increasing yuzu ingestion. Naringin and hesperidin were detected at $1.77 \mathrm{mg} \%$ and $1.63 \mathrm{mg} \%$ in sample $\mathrm{Y120}$, respectively, while trace amounts were detected in samples $\mathbf{C 8 0}+\mathrm{Y} 40$ and $\mathbf{C 4 0}+\mathrm{Y80}$, but none were detected in the control. The total polyphenol and flavonoid contents increased with increasing level of $y u z u$ ingestion, and were highest in sample Y120 $(123.11 \mathrm{mg} \%$ and $5.69 \mathrm{mg} \%$, respectively).
\end{abstract}

Key words : Tenebrio molitor L, yuzu, quality characteristics, supplemented feed, functionality

\section{서 론}

국제식량농업기구(UN Food and Agricultural Organization, UN FAO)에서는 2050년에 전 세계 인구가 약 90억명에 이를 것으로 전망하고 있다. 인구 증가 및 경제적 규모의 확대에 의한 식량 부족 문제를 해결하기 위한 정책으로 국제식량농업기구(FAO)에서는 경제성과 미래지속성을 가

*Corresponding author. E-mail : hck1008@sunchon.ac.kr Phone : 82-61-750-3251, Fax : 82-61-750-3208

Received 30 July 2019; Revised 05 September 2019; Accepted 30 September 2019.

Copyright (c) The Korean Society of Food Preservation. All rights reserved.
진 식량 자원으로 식용곤충 활성화 방안을 발표하여 전 세계적으로 식용 곤충에 크게 주목하고 있다. 이에 따라 국내에서도 2011년 1차 곤충산업육성 5개년 종합계획을 발표하고 2016년 제2차 곤충산업육성 5개년 종합계획을 발표하는 등 곤충산업에 대한 관심이 증가하고 있다. 곤충 은 개체 크기가 작아 사육 할 수 있는 공간이 좁기 때문에 토지의 이용효율이 높고 수많은 알을 수백개 까지 낳을 수 있어 빠른 시간 내에 대량으로 생산할 수 있으며 육류를 사육하는데 필요한 사료량 보다 매우 적은 사료로 사육할 수 있는 장점이 있다. 이처럼 곤충은 여러 역할을 수행할 수 있어 산업발전의 가능성을 보여주고 있다(2). 세계 곤충 시장 규모는 2017년 11조원에서 2020년에 약 38조원에 이 를 것으로 전망하고 있으며, 식용곤충 시장규모는 2023년 
까지 연평균 $40 \%$ 이상 성장할 것으로 예견하고 있다(3). 식 용으로 이용되고 있는 곤충으로는 딱정벌레목(Coleoptera), 나비목(Lepidoptera), 메뚜기목(Orthoptera), 흰개미목(Isoptera) 과 벌목(Hymenoptera) 등이 있으며 국내에서는 쌍별귀뚜라 미, 흰점박이꽃무지 유충, 장수풍뎅이 유충, 메뚜기 등이 식품원료로 사용되고 있다(4). 갈색거저리(Tenebrio molitor L.)는 딱정벌레목 거저리과에 속하며, 2014년 농촌진흥청 에서 독성검사를 통해 한시적 식품원료로 인정되었으며, 2016년에는 인체에 대한 영양성과 안전성을 규명 받아 그 결과를 바탕으로 식품의약품안전처(Ministry of Food and Drug Safety, MFDS)에 현재 식품 원료로 인정을 받은 상황 이다(5). 갈색거저리는 이미 네덜란드, 미국, 일본, 중국 등 많은 서양 및 아시아 국가에서 식용으로 사용되고 있는 곤충이다(6). 그 중 중국에서는 갈색거저리가 동물의 면역 력을 강화하고 동물체 기능을 개선하여 유해물질의 생장 및 번식을 억제하는 것으로 알려져 있으며, 대량사육기술 과 건조방법 등이 상용화되어 공장화되고 있다(7). 국내에 서는 일반 식품 원료로 인증 받기 전에도 비교적 산업화가 많이 진행되어 있었고, 고소한 맛을 내는 애벌레로 “고소 애”라는 명칭이 붙을 만큼 맛이 우수하여 크게 각광받고 있다. 번식률이 높고 사육조건이 까다롭지 않아 단기간에 대량생산이 가능하며 연중 사육할 수 있어 산업화가 비교적 용이하며 다른 곤충에 비해 크기가 작고 머리와 다리의 비율이 낮으며 배 부분의 비율이 높아 개별 체적 내 분포가 비교적 균일하여 단일 개체 내 부위에 따른 색, 맛 등의 차이가 거의 없어 가공 시간 단축과 가공 적성에 있어서 큰 이점이 있다(8). 또한 갈색거저리 유충은 육류와 유사한 수준의 양질의 단백질을 함유하고 있으며 불포화지방산과 필수 아미노산이 풍부하고 비타민과 무기질 등 미량영양소 함량도 높아 영양적으로 우수한 장점을 지니고 있다(9). 이처럼 영양학적으로 우수한 갈색거저리를 Yoo 등(7)은 국내산과 중국산으로 분류하여 영양성분을 비교 분석한 결과 조지방과 지방산의 경우만 약간의 유의적인 차이가 있었고, 그 외 성분은 비슷하다고 보고해 우리나라 갈색거 저리의 품질을 보고한바 있다.

감귤류의 일종인 유자(Citrus junos SIEB ex TANAKA)는 국내에서 전라남도 고흥, 완도, 진도, 장흥과 경상남도 거제, 통영, 남해 그리고 제주도 등지에서 재배되고 있다. 유자는 레몬에 비해 3 배 정도 많은 비타민 $\mathrm{C}$ 가 들어 있어 감기와 피부미용에 좋고 유기산이 풍부하여 노화와 피로방지에도 효과적이며 무기질의 함량도 높다고 알려져 있다(10). 유자 를 비롯한 감귤류의 과피에 함유되어 있는 플라보노이드류 는 다양한 생리활성을 지니며 나린진은 항균, 항산화, 항염 증, 항고혈압 및 혈중지질 저하 효과 등이 보고되었고 헤스 페리딘은 혈압강하, 항알러지, 혈중 $\mathrm{LDL}$ 콜레스테롤 감소, 발암 억제 작용 등의 유자의 기능성이 밝혀지면서 소비를 활성화하기 위한 기술 및 상품이 개발되고 있다(11). 이러한
유자의 기능성 등을 활용해 다양한 식품 등이 출시되고 있으며, 유자를 사료로 활용하는 연구 또한 보고된 바 있다. Kim 등(12)과 Hwang 등(13)은 유자 첨가 사료로 사육한 넙치와 뱀장어의 영양성분 조성을 확인한 결과 유자의 영양 성분이 넙치와 뱀장어에 전이 되면서 품질 개선에 효과가 있었다고 보고하였고, Jung 등(14)은 유자 첨가 사료가 넙치 의 질병저항성에 미치는 영향을 조사한 결과 폐사가 지연되 는 효과를 보였다고 보고해 유자를 사료로 활용할 수 있는 요인들이 확인되었다.

갈색거저리에 대한 선행연구는 형태적 특징, 키틴합성 저해제의 활성평가(15) 및 항진균 단백질(16) 등의 연구가 진행 되어졌으며, 최근에 생태적 특성과 갈색거저리의 영 양성분(7)에 대한 연구 등이 이루어졌다. 하지만 갈색거저 리의 식이 사료에 따른 곤충의 품질 개선 및 기능성 향상에 관한 연구는 현재까지 미흡한 실정이다. 일반적으로 갈색 거저리 사육시 주 먹이원은 밀기울을 사용하고 있고, 수분 과 그 외 영양성분 공급을 위해 배추를 많이 사용한다(17). 본 연구에서는 사료 보충제 배추를 유자와 함께 혼합해서 사육시 유자의 영양 성분이 갈색거저리로 전이되어 품질 개선 효과가 있을 것이라는 가설을 설정하였다. 따라서 주 먹이원인 밀기울은 기존에 공급했던 내역으로 구성하고, 사료 보충제인 배추 먹이원을 유자와 혼합 비율을 달리해 사료로 구성하여 유자를 섭취한 갈색거저리의 품질을 비교 하였다.

\section{재료 및 방법}

\section{실험재료}

본 실험에 사용한 유자 첨가 사료 보충제 식이 갈색거저 리(Tenebrio molitor L.)는 전라남도 고흥군농업기술센터의 곤충 사육실에서 사육되었다. 사육 형태는 배추(대한민국) 와 유자 과피(대한민국)의 혼합 비율에 따른 각각의 시료별 3 개의 사육 상자(개당 상자 크기 : $615 \times 380 \times 90 \mathrm{~mm}$ )씩 구성 해서 사육 하였고, 사육이 완료된 갈색거저리는 2 일간 절식 후 사육 상자별로 마이크로웨이브건조기(WJ-MW100, Hwajin Co., Gwangju, Korea)로 건조온도 $75-80^{\circ} \mathrm{C}$ 에서 7-8 분 건조하였으며, 균질하게 분쇄 하여 $-20^{\circ} \mathrm{C}$ 에서 냉동 보관 하면서 시료로 사용하였다. 본 실험에서 사용된 분석 및 chromatography 사용 용매인 acetonitrile(HPLC용)은 J.TBaker사(Phillipsburg, NJ, USA)에서 구매하였고, Folindenis reagent, tannin acid, quercetin과 naringin, hesperidin 표준품은 Sigma Aldrich Chemical Co.(St. Louis, MO, USA) 에서 구입하였다. 기타 사용된 시약은 특급 및 $\mathrm{High}$ performance liquid chromatography 등급을 사용하였다. 


\section{사료 식이 및 사육 방법}

갈색거저리 사육을 위한 배추와 유자 과피의 혼합 비율 에 따른 사료 보충제 시료구의 조성은 Table 1과 같다. 식이 방법은 밀기울(대한민국)을 주 사료로 공급하고 수분과 그 외 영양성분 공급을 위해 배추와 유자 과피의 혼합비율에 따른 각각의 사료 보충제 $120 \mathrm{~g}$ 을 2-3일 간격으로 총 90 일간 공급하였고(평균 공급량, 주령에 따라 차이가 있음), $25^{\circ} \mathrm{C}$ 항온항습시설(상대습도 $60-70 \%$, 광조건 $14 \mathrm{~L}: 10 \mathrm{D}$ )에서 90 일간 사육하였으며, 이후 $28-35 \mathrm{~mm}$ 의 유충을 2 일간 절식 후 마이크로웨이브건조기(WJ-MW100, Hwajin Co., Gwangju, Korea)로 건조한 갈색거저리를 분말화 하였다.

Table 1. Feed composition

\begin{tabular}{ccc}
\hline \multirow{2}{*}{ Samples } & \multicolumn{2}{c}{ Feed composition } \\
\cline { 2 - 3 } & Chinese cabbage (g) & Yuzu peel $(\mathrm{g})$ \\
\hline C120 & 120 & - \\
C80+Y40 & 80 & 40 \\
C40+Y80 & 40 & 80 \\
Y120 & - & 120 \\
\hline
\end{tabular}

\section{일반성분 분석}

일반성분은 $\mathrm{AOAC}$ 방법(18)에 따라 분석하였다. 즉, 수 분은 시료 $3 \mathrm{~g}$ 을 각각 칭량병에 담고 $105^{\circ} \mathrm{C}$ dry oven에서 항량이 될 때까지 건조시켜 무게를 측정하여 구하였고, 조 단백질의 함량은 Kjeldahl법으로 측정된 질소량에 질소계 수 6.25를 곱하여 산출하였으며, 조지방의 함량은 soxhlet 추출법으로 정량하였다. 조회분은 시료 $1 \mathrm{~g}$ 을 $250^{\circ} \mathrm{C}$ 에서 예비 회화한 후 $600^{\circ} \mathrm{C}$ 에서 회화하는 직접 회화법으로 하였 다.

\section{색도 측정}

색도 측정은 시료 일정량을 취해 색도계(super color $\mathrm{sp}-80$, Tokyo, Denshoku, JAPAN)를 이용해 $\mathrm{X}=80.84$, $\mathrm{Y}=82.22, \mathrm{Z}=92.98$ 인 표준 백색판(standard white plate)으로 보정하여 사용하였다. 측정값은 명도를 나타내는 $\mathrm{L}$ 값 (lightness), 적색을 나타내는 a 값(redness) 및 황색을 나타내 는 $\mathrm{b}$ 값(yellowness)으로 나타내었다.

\section{무기성분 및 중금속 분석}

무기성분 및 중금속 분석은 식품공전(19)의 건식분해법 에 의하여 전처리하여 분석하였다. 즉, 시료 $2 \mathrm{~g}$ 를 칭량하여 $550-600^{\circ} \mathrm{C}$ 로 회화 시킨 후 증류수 $1 \mathrm{~mL}$ 와 질산 $0.5 \mathrm{~mL}$ 를 가하여 heating plate에서 백연현상이 일어날 때 까지 가열 시킨 다음 질산 $0.5 \mathrm{~mL}$ 를 가한 후 증류수로 $100 \mathrm{~mL}$ 로 정용 하여 검액으로 하였다. 각 무기성분의 정량은 원자흡광비 색계(Perkin Elmer Analyst 300, Perkin Elmer Co, Norwalk, $\mathrm{CT}, \mathrm{USA}$ )로 각 원소의 표준용액 농도를 1,3 및 $5 \mathrm{ppm}$ 으로
조제하여 표준검량 곡선을 작성하여 분석하였다.

\section{유리아미노산 분석}

유리 아미노산 분석은 Ohara와 Ariyosh의 방법(20)으로 분석하였다. 즉, 시료 $1 \mathrm{~g}$ 에 증류수를 혼합하여 $100 \mathrm{~mL}$ 로 정용한 다음 원심분리하여 상징액 $10 \mathrm{~mL}$ 를 취해 sulfosalicylic acid $25 \mathrm{mg}$ 을 가하여 $4^{\circ} \mathrm{C}$ 에서 4 시간 동안 방치 시킨 후 원심분리 하여 단백질 등을 제거하였다. 그 상징액 을 $0.45 \mu \mathrm{m}$ membrane filter(Millipore Co., Billerica, MA, USA)로 여과하여 얻은 여액을 일정량 취한 다음 아미노산 자동분석기(Biochrom 30+ Amino Acid Analyser, Cambridge, USA)를 이용하여 다음과 같은 조건으로 분석하였다. Buffer solution은 sodium citrate buffer(pH 2.80, 3.00, 3.15, $3.50,3.55)$ 을 사용하였고, buffer flow rate는 $0.42 \mathrm{~mL} / \mathrm{min}$, ninhydrin flow는 $0.33 \mathrm{~mL} / \mathrm{min}$, injection volume은 $20 \mu \mathrm{L}$, column온도는 $37^{\circ} \mathrm{C}$, 반응온도는 $135^{\circ} \mathrm{C}$ 로 분석하였다.

\section{나린진 및 히스피리딘 분석}

나린진, 히스피리딘 분석은 분쇄된 시료 $10 \mathrm{~g}$ 에 증류수를 가하여 $100 \mathrm{~mL}$ 로 정용한 다음 $80^{\circ} \mathrm{C}$ 항온수조에서 30 분간 가온 추출하고 원심분리 $(3000 \mathrm{rpm}, 30 \mathrm{~min})$ 시켜 상등액을 취하여 $0.45 \mathrm{\mu m}$ membrane filter로 여과한 여액을 HPLC(1260 Series, Agilent CO., Darmstadt, Germany)를 이 용하여 분석하였다. Column은 Sunfire $\mathrm{C}_{18}(4.6 \times 250 \mathrm{~mm}, 5 \mu$ $\mathrm{M}$, Waters co, MA, USA)을 사용하였고, mobile phase는 $20 \%$ acetonitrile, flow rate $1.0 \mathrm{~mL} / \mathrm{min}$, injection volume 30 $\mu \mathrm{L}$ 사용하였다. 표준물질(naringin, hesperidin)을 시료와 동 일한 조건에서 분석하여 머무름 시간을 비교해 확인하였으 며, 검량곡선으로부터 그 함량을 산출하였다

\section{총 폴리페놀 및 총 플라보노이드 분석}

총 폴리페놀 함량은 Folin-Denis법(21)에 준하여 측정하 였다. 증류수로 희석한 시료추출물 $2 \mathrm{~mL}$ 에 Folin-Denis regent $2 \mathrm{~mL}$ 를 혼합한 뒤 3 분 방치 후 $5 \% \mathrm{NaCO}_{3} 5 \mathrm{~mL}$ 를 혼합하고 1 시간 방치 한 다음 $660 \mathrm{~nm}$ 에서 흡광도를 측정하 였다. 표준물질로는 tannic acid를 사용하였다. 총 플라보노 이드 함량은 Davis 변법(22)에 따라 측정하였다. 시료추출 물 $1 \mathrm{~mL}$ 에 diethylene glycol $10 \mathrm{~mL}$ 와 $1 \mathrm{~N} \mathrm{NaOH} 1 \mathrm{~mL}$ 를 혼합한 뒤 $30^{\circ} \mathrm{C}$ 에서 60 분간 유지 시킨 다음 $420 \mathrm{~nm}$ 에서 흡광도를 측정하였다. Quercetin의 검량선을 이용하여 플라 보노이드 함량을 계산하였다.

\section{통계처리}

모든 실험 결과는 3회 이상 반복하여 평균표준편차로 나타내었으며, SPSS 프로그램(25, IBM Corp Armonk, NY, USA)을 사용하여 분산 분석을 수행하였다. 각 시료의 분석 결과에 대한 유의성 검정은 분산 분석을 한 후 $\mathrm{p}<0.05$ 수준 
에서 Duncan's multiple range test를 실시하였다.

\section{결과 및 고찰}

\section{일반성분}

유자 첨가 비율에 따른 사료 보충제 식이 갈색거저리 건조 분말의 일반성분 분석 결과는 Table 2 와 같다. 수분 함량은 $\mathrm{C} 80+\mathrm{Y} 40$ 시료구가 $0.50 \%$ 로 가장 높은 수분함량을 보였고, C120, C40+Y80, Y120 순으로 나타나 시료간의 유의적인 차이는 보이지 않았다. 조단백질 함량은 52.58-53.90\% 범위였고, 조지방 함량은 30.76-32.34\%, 조회 분 함량은 3.32-3.45\% 수준으로 Lee 등(23)의 일반 사료 조성(유자가 첨가되지 않은 사료 조성)으로 사육한 갈색거 저리 건조 분말의 일반성분 분석 결과와 유사한 결과를 나타내어 유자가 첨가된 사료 식이가 갈색거저리의 일반 성분 조성에 크게 영향을 미치지 않은 것을 확인 하였고, 시료구별 유의적 차이 또한 보이지 않았다.

Table 2. Proximate analysis of Tenebrio molitor L. ingested yuzu supplemented feed

\begin{tabular}{ccccc}
\hline Sample $^{1)}$ & Moisture & Crude protein & Crude fat & Crude ash \\
\hline C120 & $0.49 \pm 0.02^{\mathrm{NS} 2)}$ & $53.36 \pm 0.44^{\mathrm{NS}}$ & $31.04 \pm 0.58^{\mathrm{NS}}$ & $3.32 \pm 0.07^{\mathrm{NS}}$ \\
$\mathrm{C} 80+\mathrm{Y} 40$ & $0.50 \pm 0.06$ & $52.58 \pm 0.55$ & $30.76 \pm 1.09$ & $3.45 \pm 0.13$ \\
$\mathrm{C} 40+\mathrm{Y} 80$ & $0.48 \pm 0.02$ & $53.90 \pm 1.35$ & $32.34 \pm 1.42$ & $3.35 \pm 0.10$ \\
$\mathrm{Y} 120$ & $0.47 \pm 0.04$ & $52.78 \pm 1.39$ & $31.47 \pm 1.34$ & $3.39 \pm 0.08$ \\
\hline
\end{tabular}

See the legend of Table 1.

${ }^{2} \mathrm{NS}$, not significant.

\section{색 도}

유자 첨가 비율에 따른 사료 보충제 식이 갈색거저리 건조 분말의 색도 측정 결과는 Table 3 과 같다. 명도를 나타 내는 L값(lightness)은 $\mathrm{C} 80+\mathrm{Y} 40$ 시료구와 $\mathrm{C} 40+\mathrm{Y} 80$ 시료구 가 각각 $36.28,35.22$ 로 높게 나타나 배추만 섭취한 $\mathrm{C} 120$ 시료구와 유자만 섭취한 Y120 시료구 보다 유의적으로 높 은 값을 보였다. 적색도를 나타내는 a값(redness)은 C120 시료구가 10.89 로 가장 높게 나타났으며, C80+Y40, $\mathrm{C} 40+\mathrm{Y} 80, \mathrm{Y} 120$ 시료구순으로 유의적 차이 $(\mathrm{p}<0.05)$ 를 보였 다. Kim 등(24)은 유자 과피를 첨가하여 제조한 진양주의 색도를 측정 결과 유자 과피 첨가량이 증가할수록 적색도가 감소한다고 보고하였으며, 이는 본 실험의 결과와 유사한 경향을 나타냈다. 황색도를 나타내는 b값(yellowness)은 C120 시료구가 19.20으로 가장 높게 나타났으나, C40+Y80 시료구가 15.65 로 가장 낮게 나타나 유자 섭취량에 따른 유의적 차이는 보이지 않았다. 본 연구 결과 유자 섭취량에 따라 적색도가 감소하는 경향을 보였으며 이는 유자 섭취가
갈색거저리의 적색도에 영향을 미치는 것으로 사료된다.

Table 3. Hunter's color value of Tenebrio molitor $\mathrm{L}$. ingested yuzu supplemented feed

\begin{tabular}{cccc}
\hline Sample $^{1)}$ & $\mathrm{L}$ & $\mathrm{a}$ & $\mathrm{b}$ \\
\hline C120 & $34.00 \pm 1.17^{22}$ & $10.89 \pm 0.34^{\mathrm{a}}$ & $19.20 \pm 1.39^{\mathrm{a}}$ \\
C $80+\mathrm{Y} 40$ & $36.28 \pm 0.88^{\mathrm{a}}$ & $10.76 \pm 0.47^{\mathrm{a}}$ & $18.45 \pm 0.90^{\mathrm{a}}$ \\
C40+Y80 & $35.22 \pm 1.05^{\mathrm{b}}$ & $10.39 \pm 0.38^{\mathrm{b}}$ & $15.65 \pm 2.77^{\mathrm{b}}$ \\
Y120 & $33.65 \pm 1.57^{\mathrm{c}}$ & $10.13 \pm 0.32^{\mathrm{b}}$ & $17.87 \pm 0.84^{\mathrm{a}}$ \\
\hline
\end{tabular}

${ }^{1)}$ See the legend of Table 1 .

${ }^{2)}$ Mean \pm SD with different superscripts within the same column are significantly different $(p<0.05)$ by Duncan's multiple range test. $a>b>c$.

\section{무기성분 및 중금속}

유자 첨가 사료 보충제 식이 갈색거저리의 무기성분 분 석 결과는 Table 4 와 같다. 갈색거저리의 무기성분 구성 원소는 칼륨의 함량이 $1,603.47-1,710.17 \mathrm{mg} \%$ 로 다른 무기 성분에 비해 높게 나타났다. 구성 원소별 함량을 보면 칼슘 은 $\mathrm{C} 120$ 시료구가 $77.63 \mathrm{mg} \%$ 로 유자를 섭취한 시료구의 61.48-66.25 mg\%에 비해 유의적으로 높게 나타나 유자 첨 가량이 증가할수록 낮은 함량을 보였다. 칼륨의 함량은 유 자의 섭취량이 가장 많은 $\mathrm{Y} 120$ 시료구가 $1,710.17 \mathrm{mg} \%$ 로 가장 높게 나타났으며 $\mathrm{C} 40+\mathrm{Y} 80, \mathrm{C} 80+\mathrm{Y} 40, \mathrm{C} 120$ 시료구순 으로 유자 첨가량이 증가할수록 칼륨의 함량이 유의적으로 증가하였다. Song 등(25)은 유자 과피의 무기성분을 분석한 결과 칼륨이 가장 높게 정량되었다고 하였는데 실험결과 유자 첨가량에 따라 칼륨 함량이 증가해 갈색거저리의 유자 식이에 의해 칼륨 성분이 전이된 것으로 생각된다. 마그네 슘 함량 또한 $\mathrm{Y} 120$ 시료구가 $569.10 \mathrm{mg} \%$ 로 가장 높게 나타 났으며 $\mathrm{C} 40+\mathrm{Y} 80, \mathrm{C} 80+\mathrm{Y} 40, \mathrm{C} 120$ 시료구순으로 유자 첨가 량이 증가할수록 마그네슘의 함량이 유의적으로 증가하였 다. 아연의 함량은 유자를 섭취한 $\mathrm{C} 80+\mathrm{Y} 40, \mathrm{C} 40+\mathrm{Y} 80$, $\mathrm{Y} 120$ 3개의 시료구가 유자를 섭취 하지 않은 $\mathrm{C} 120$ 시료구 에 비해 약간 높은 함량을 보였으나 유의적 차이는 보이지 않았다. 칼륨은 체내에서 삼투압과 수분평형 유지에 관여 하며 에너지 대사 및 뇌에 산소를 보내 뇌의 기능에 도움을 준다. 또한 몸속의 노폐물 처리와 혈압을 낮추는 효과로 인해 고혈압의 예방 및 치료에 도움을 주는 것으로 알려져 있는 성분으로(26) 갈색거저리에 다량 함유되어 있는 것으 로 확인되었다. 갈색거저리의 중금속에 대한 안전성 확인 하기 위해 유자 사료 식이 조건에 따른 갈색거저리의 납과 비소에 대한 분석을 실시하였다. 분석 결과 모든 시료구에 서 검출되지 않아 식약처 고시(27)의 기준에 적합한 것으로 확인 되었다.

\section{유리아미노산}

유리아미노산은 식품의 맛에 직접적으로 연관되어있다. 
아미노산의 종류에 따라 다른 맛을 가지고 있으며 serine 및 alanine 등이 단맛에 histidine, arginine 등이 쓴맛에 영향 을 미치는 것으로 알려져 있다(28). 따라서 유리아미노산 함량 분석 또한 중요한 실험 요소로써 갈색거저리의 사료 식이 조건에 따른 아미노산 함량을 분석 하였다(Table 5). 일반적으로 갈색거저리의 유리 아미노산 조성 분석 결과(8)
를 보면 총 19 종의 유리아미노산이 검출되었다고 보고 하 고 있으나 본 연구에서는 tryptophan을 제외한 18종의 유리 아미노산이 검출되었다. 이는 갈색거저리의 식이 조건과 건조 조건에 의한 아미노산 조성이 달라졌다고 판단된다. 아미노산 성분별 분석 결과를 보면 proline과 arginine이 각 각 470.08-515.95 mg\%, 335.15-380.41 mg\%로 가장 높게

Table 4. The contents of mineral in Tenebrio molitor L. ingested yuzu supplemented feed

\begin{tabular}{|c|c|c|c|c|c|c|c|}
\hline \multirow{2}{*}{ Sample $^{1)}$} & \multicolumn{5}{|c|}{ Mineral } & \multicolumn{2}{|c|}{ Heavy metal } \\
\hline & $\mathrm{Ca}$ & K & $\mathrm{Na}$ & $\mathrm{Mg}$ & $\mathrm{Zn}$ & $\mathrm{Pb}$ & As \\
\hline $\mathrm{C} 120$ & $77.63 \pm 18.57^{22)}$ & $1,603.47 \pm 154.12^{b}$ & $94.64 \pm 7.46^{\text {NS3) }}$ & $533.82 \pm 51.07^{\mathrm{b}}$ & $117.09 \pm 21.11^{\mathrm{NS}}$ & $\mathrm{ND}^{4)}$ & $\mathrm{ND}$ \\
\hline $\mathrm{C} 80+\mathrm{Y} 40$ & $66.25 \pm 5.72^{\mathrm{ab}}$ & $1,633.76 \pm 7.33^{b}$ & $97.93 \pm 5.16$ & $540.92 \pm 12.52^{\mathrm{ab}}$ & $121.07 \pm 13.65$ & ND & $\mathrm{ND}$ \\
\hline $\mathrm{C} 40+\mathrm{Y} 80$ & $61.48 \pm 15.13^{\text {ab }}$ & $1,660.10 \pm 35.62^{\mathrm{ab}}$ & $100.70 \pm 23.95$ & $557.58 \pm 20.15^{\mathrm{ab}}$ & $135.21 \pm 65.72$ & $\mathrm{ND}$ & $\mathrm{ND}$ \\
\hline $\mathrm{Y} 120$ & $62.00 \pm 8.42^{\mathrm{b}}$ & $1,710.17 \pm 24.03^{\mathrm{a}}$ & $88.01 \pm 12.27$ & $569.10 \pm 7.56^{\mathrm{a}}$ & $125.31 \pm 21.14$ & ND & $\mathrm{ND}$ \\
\hline
\end{tabular}

${ }^{1)}$ See the legend of Table 1 .

${ }^{2)}$ Mean \pm SD with different superscripts within the same column are significantly different $(p<0.05)$ by Duncan's multiple range test. $a>b$.

${ }^{3} \mathrm{NS}$, not significant.

${ }^{4} \mathrm{ND}$, not detected.

Table 5. The contents of free amino acid in Tenebrio molitor L. ingested yuzl supplemented feed

\begin{tabular}{|c|c|c|c|c|c|}
\hline \multicolumn{2}{|c|}{ Sample $^{1)}$} & $\mathrm{C} 120$ & $\mathrm{C} 80+\mathrm{Y} 40$ & $\mathrm{C} 40+\mathrm{Y} 80$ & Y120 \\
\hline \multirow{8}{*}{ Essential amino acids } & Valine & $207.67 \pm 34.01^{\mathrm{NS} 2)}$ & $245.83 \pm 2.46$ & $209.43 \pm 38.52$ & $208.62 \pm 53.78$ \\
\hline & Leucine & $96.84 \pm 27.72^{\mathrm{bc} 33}$ & $133.21 \pm 24.91^{\mathrm{a}}$ & $120.16 \pm 35.51^{\mathrm{ab}}$ & $79.02 \pm 16.94^{c}$ \\
\hline & Isoleucine & $102.22 \pm 45.38^{\mathrm{NS}}$ & $117.62 \pm 48.59$ & $112.05 \pm 44.28$ & $113.26 \pm 45.98$ \\
\hline & Lysine & $185.64 \pm 9.45^{\mathrm{NS}}$ & $170.28 \pm 39.77$ & $197.81 \pm 25.89$ & $156.70 \pm 10.56$ \\
\hline & Histidine & $233.27 \pm 28.90^{\mathrm{a}}$ & $195.02 \pm 39.26^{\mathrm{ab}}$ & $195.18 \pm 64.12^{\mathrm{ab}}$ & $171.66 \pm 36.00^{b}$ \\
\hline & Methionine & $44.88 \pm 3.67^{\mathrm{NS}}$ & $42.64 \pm 14.15$ & $48.59 \pm 33.00$ & $38.53 \pm 17.87$ \\
\hline & Threonine & $44.21 \pm 55.19^{\mathrm{NS}}$ & $92.88 \pm 11.27$ & $43.58 \pm 40.47$ & $83.68 \pm 13.54$ \\
\hline & Phenylalanine & $52.88 \pm 9.73^{\mathrm{ab}}$ & $80.82 \pm 25.75^{\mathrm{a}}$ & $72.58 \pm 19.71^{\mathrm{ab}}$ & $37.31 \pm 20.76^{b}$ \\
\hline \multirow{10}{*}{$\begin{array}{l}\text { Non-essential amino } \\
\text { acids }\end{array}$} & Proline & $477.48 \pm 76.06^{\mathrm{NS}}$ & $515.95 \pm 39.87$ & $475.00 \pm 22.40$ & $470.08 \pm 92.81$ \\
\hline & Alanine & $292.59 \pm 83.52^{\mathrm{NS}}$ & $350.22 \pm 44.43$ & $333.85 \pm 11.22$ & $331.73 \pm 66.76$ \\
\hline & Tyrosine & $182.72 \pm 18.43^{\mathrm{NS}}$ & $246.42 \pm 60.45$ & $236.08 \pm 72.60$ & $229.50 \pm 54.17$ \\
\hline & Arginine & $380.41 \pm 49.46^{\mathrm{NS}}$ & $351.33 \pm 11.31$ & $337.05 \pm 61.94$ & $335.15 \pm 47.42$ \\
\hline & Glutamic acid & $134.80 \pm 39.79^{\mathrm{NS}}$ & $106.42 \pm 68.28$ & $127.72 \pm 97.09$ & $144.21 \pm 32.49$ \\
\hline & Glycine & $80.25 \pm 15.24^{\mathrm{NS}}$ & $84.04 \pm 15.20$ & $81.55 \pm 15.09$ & $65.29 \pm 5.25$ \\
\hline & Serine & $22.27 \pm 13.32^{\mathrm{NS}}$ & $34.05 \pm 7.84$ & $30.95 \pm 2.43$ & $29.93 \pm 6.82$ \\
\hline & Aspartic acid & $18.14 \pm 13.32^{\mathrm{NS}}$ & $18.81 \pm 4.83$ & $12.81 \pm 3.29$ & $18.44 \pm 11.74$ \\
\hline & Asparagine & $91.89 \pm 72.96^{\mathrm{NS}}$ & $57.97 \pm 46.72$ & $68.94 \pm 38.90$ & $154.12 \pm 186.51$ \\
\hline & Cystine & $16.64 \pm 4.77^{\mathrm{NS}}$ & $23.97 \pm 16.90$ & $24.83 \pm 4.38$ & $14.93 \pm 3.71$ \\
\hline \multicolumn{2}{|c|}{$\mathrm{EAA}^{4)}$} & 967.61 & $1,078.30$ & 999.38 & 888.78 \\
\hline \multicolumn{2}{|c|}{ TAA } & $2,784.8$ & $2,947.48$ & $2,768.16$ & $2,802.16$ \\
\hline
\end{tabular}

\footnotetext{
${ }^{1)}$ See the legend of Table 1 .

${ }^{2)} \mathrm{NS}$, not significant.

${ }^{3)}$ Mean \pm SD with different superscripts within the same column are significantly different $(p<0.05)$ by Duncan's multiple range test. $a>b>c$.

${ }^{4}$ EAA: essential amino acids; TAA: total amino acids.
} 
나타나 갈색거저리의 주요 유리아미노산으로 확인되었으 며, 시료구별 총 유리아미노산 함량은 2,664.8-2,867.48 $\mathrm{mg} \%$ 의 함량을 보였으나 시료구별 유의적인 차이는 보이지 않았다. 필수 아미노산 함량은 888.78-1,078.30 mg\% 범위 로 총 유리아미노산 함량의 $33-37 \%$ 를 차지하였으나 시료 구별 유의적인 차이는 없었다. 필수아미노산 중에서 valine, lysine, histidine이 각각 $207.67-245.83 \mathrm{mg} \%, 156.70-197.87$ $\mathrm{mg} \%, 171.66-233.27 \mathrm{mg} \%$ 로 다른 필수 아미노산 함량에 비해 높은 함량을 보였다. 전남농업기술원 곤충잠업연구소 에서 보고한 열풍 건조 갈색거저리 유리아미노산 조성을 보면(5) proline과 arginine이 주요아미노산으로 확인되었다 고 하였으며, 필수아미노산 함량이 $0.9 \%$ 라고 보고하여 본 실험과 유사한 경향을 나타냈다. 필수아미노산 중에서는 proline, alanine, tyrosine, arginine이 각각 470.08-515.95 $\mathrm{mg} \%$, 292.59-350.22 mg\%, 182.72-246.42 mg\%, 335.15$380.41 \mathrm{mg} \%$ 로 다른 비필수 아미노산 함량에 비해 높은 함량을 보였다. Yoo 등(7)의 연구에 따르면 동결 건조한 갈색거저리의 비필수아미노산 중 glutamic acid가 가장 많 았다고 보고하였으나 전남 농업기술원 곤충잠업연구소에 서 보고한(5) 열풍 건조한 갈색거저리에서는 낮은 함량을 보여 개체나 건조 조건에 따라 다소 차이가 있는 것으로 생각된다. 단맛에 영향을 미치는 serine과 alanine은 유자를 섭취한 $\mathrm{C} 80+\mathrm{Y} 40, \mathrm{C} 40+\mathrm{Y} 80, \mathrm{Y} 120$ 3개의 시료구가 $\mathrm{C} 120$ 시료구에 비해 약간 높은 함량을 보였고, 쓴맛에 영향을 미치는 histidine과 arginine은 C80+Y40, C40+Y80, Y120 3 개의 시료구가 $\mathrm{C} 120$ 시료구에 비해 감소하는 경향을 보였 지만 serine, alanine, arginine은 유의적인 차이는 보이지 않 았다. 연구 결과 갈색거저리는 아미노산을 풍부하게 함유 하고 있어 좋은 단백질 공급원임을 확인할 수 있었다.

\section{나린진 및 히스피리딘}

나린진 성분은 감귤류의 외피나 내피에 함유된 정유나 배당체의 일종인 과실의 쓴맛성분으로 항산화계 효소들의 활성방지와 항균작용이 있다고 보고되어 있고(29), 히스피 리딘 성분 또한 유자의 지표 성분으로 보고되고 있으며 연한 노란색의 결정 또는 결정성 가루로 혈중 콜레스테롤 농도 상승억제작용, 항산화작용, 지방간 억제작용이 있다 고 보고되어 있다(30). 따라서 유자 첨가 사료 보충제 식이 갈색거저리의 나린진과 히스피리딘 포함 여부를 확인하기 위해 함량 분석을 실시하였다. 갈색거저리의 유자 사료 식 이 조건에 따른 나린진, 히스피리딘 함량 분석 결과는 Table 6 과 같다. 나린진 성분을 분석한 결과 유자를 섭취하지 않은 $\mathrm{C} 120$ 시료구에서는 검출되지 않았으며, $\mathrm{C} 80+\mathrm{Y} 40$, $\mathrm{C} 40+\mathrm{Y} 80, \mathrm{Y} 120$ 3개의 시료구는 각각 $0.20 \mathrm{mg} \%, 0.79 \mathrm{mg} \%$, $1.77 \mathrm{mg} \%$ 순으로 유자 섭취량에 따라 유의적으로 증가하는 것으로 나타났다( $<<0.05)$. 히스피리딘 성분을 분석한 결과 또한 유자를 섭취하지 않은 $\mathrm{C} 120$ 시료구와 $\mathrm{C} 80+\mathrm{Y} 40$ 시료
구에서는 검출되지 않았지만 $\mathrm{C} 40+\mathrm{Y} 80, \mathrm{Y} 120$ 시료구에서 는 각각 $0.67 \mathrm{mg} \%, 1.63 \mathrm{mg} \%$ 순으로 유의적으로 증가하는 것으로 나타났다 $(\mathrm{p}<0.05)$. 앞서 언급했듯이 나린진과 히스 피리딘 성분은 다양한 기능성을 갖는 물질로 알려져 있다. 따라서 본 연구에서 실시한 유자를 섭취한 갈색거저리에서 나린진과 히스피리딘 성분이 검출된 결과는 품질 개선 효과 에 도움을 줄 수 있는 요인으로 판단된다.

Table 6. The contents of naringin and hesperidin in Tenebrio molitor L. ingested yuzı supplemented feed

\begin{tabular}{ccc} 
& & \\
\hline Sample $^{1)}$ & Naringin & Hesperidin \\
\hline C120 & $\mathrm{ND}^{2)}$ & $\mathrm{ND}$ \\
$\mathrm{C} 80+\mathrm{Y} 40$ & $0.20 \pm 0.34^{\mathrm{b3})}$ & $\mathrm{ND}$ \\
$\mathrm{C} 40+\mathrm{Y} 80$ & $0.79 \pm 0.10^{\mathrm{a}}$ & $0.67 \pm 0.11^{\mathrm{b}}$ \\
$\mathrm{Y} 120$ & $1.77 \pm 0.74^{\mathrm{a}}$ & $1.63 \pm 0.63^{\mathrm{a}}$ \\
\hline
\end{tabular}

${ }^{1)}$ See the legend of Table 1 .

${ }^{2)} \mathrm{ND}$, not detected.

${ }^{3} \mathrm{Mean} \pm \mathrm{SD}$ with different superscripts within the same column are significantly different $(p<0.05)$ by Duncan's multiple range test. $a>b$.

\section{총 폴리페놀 및 총 플라보노이드}

폴리페놀 화합물(플라보노이드 화합물 포함)은 식물계 에 널리 분포되어 있는 2 차대사 산물의 하나로 $\mathrm{ROS}$ 에 의한 세포 수준이나 DNA 등의 손상을 억제하기 위한 방어 메커 니즘을 제공한다고 알려져 있다(31). 유자 첨가 사료 보충제 식이 갈색거저리의 총 폴리페놀 함량과 총 플라보노이드 함량 분석 결과는 Table 7과 같다. 총 폴리페놀 함량은 유자 를 섭취하지 않은 $\mathrm{C} 120$ 시료구가 $90.26 \mathrm{mg} \%$ 로 낮은 함량을 보였고 유자를 가장 많이 섭취한 Y120 시료구가 123.11 $\mathrm{mg} \%$ 로 가장 높은 함량을 보였지만 $\mathrm{C} 80+\mathrm{Y} 40$ 시료구의 경 우는 $\mathrm{C} 120$ 시료구의 함량 보다 낮게 나타났다 $(\mathrm{p}<0.05)$. 총 플라보노이드 함량은 유자를 섭취하지 않은 $\mathrm{C} 120$ 시료구 가 $2.29 \mathrm{mg} \%$ 였고, C80+Y40, C40+Y80, $\mathrm{Y} 120$ 3개의 시료구 는 각각 $2.82 \mathrm{mg} \%, 3.89 \mathrm{mg} \%$, 그리고 $5.69 \mathrm{mg} \%$ 로 유자 섭취량에 따라 총 플라보노이드 함량이 유의적으로 증가하

Table 7. Total polyphenols and flavonoids content of Tenebrio molitor L. ingested yuzı supplemented feed

\begin{tabular}{ccc} 
& & $(\mathrm{mg} \%)$ \\
\hline Sample $^{1)}$ & Total polyphenols & Total flavonoids \\
C120 & $90.26 \pm 20.60^{\mathrm{b} 2)}$ & $2.29 \pm 1.19^{\mathrm{c}}$ \\
C80+Y40 & $73.00 \pm 15.27^{\mathrm{b}}$ & $2.82 \pm 1.75^{\mathrm{bc}}$ \\
C40+Y80 & $117.10 \pm 10.00^{\mathrm{a}}$ & $3.89 \pm 2.63^{\mathrm{b}}$ \\
Y120 & $123.11 \pm 31.57^{\mathrm{a}}$ & $5.69 \pm 2.31^{\mathrm{a}}$ \\
\hline
\end{tabular}

${ }^{1)}$ See the legend of Table 1.

${ }^{2)}$ Mean \pm SD with different superscripts within the same column are significantly different $(p<0.05)$ by Duncan's multiple range test. $a>b>c$. 
는 것으로 나타났다 $(\mathrm{p}<0.05)$. 유자는 플라보노이드 성분이 다량으로 함유되어 있는 원료로 알려져 있으며(32), 앞서 언급 했듯이 플라보노이드 성분은 다양한 기능성이 있는 것으로 알려져 있다. 본 연구에서의 유자 섭취량에 따른 갈색거저리의 총 플라보노이드 함량이 유의적으로 증가한 결과는 갈색거저리의 품질 개선에 도움을 줄 수 있을 것으 로 판단된다.

\section{요 약}

본 연구에서는 유자를 갈색거저리의 사료 보충제로 활용 해 품질특성을 확인하였다. 일반성분 분석 결과 수분, 조단 백질, 조지방 및 조회분 함량 모두 시료구별 유의적 차이를 보이지 않아 유자 식이에 따른 일반성분 조성에 미치는 영향은 크지 않은 것으로 확인되었다. 색도에서 명도와 황 색도는 시료구별 유의적 차이를 보이지 않았고, 적색도는 유자 첨가 비율이 높아질수록 감소하는 경향을 보여 유의적 차이를 보였다( $<00.05)$. 갈색거저리의 무기성분 구성 원소 는 칼륨의 함량이 $1,603.47-1,710.17 \mathrm{mg} \%$ 로 다른 무기성분 에 비해 높게 나타났다. 중금속 납과 비소를 분석한 결과 모든 시료구에서 검출되지 않았다. 단맛에 영향을 미치는 아미노산인 serine과 alanine은 유자를 섭취한 시료구가 $\mathrm{C} 120$ 시료구에 비해 약간 높은 함량을 보였고, 쓴맛에 영향 을 미치는 histidine과 arginine은 $\mathrm{C} 120$ 시료구에 비해 감소 하는 경향을 보였다. 나린진, 히스피리딘 성분의 경우 유자 섭취량에 따라 유의적으로 증가하는 것으로 나타났다. 총 폴리페놀 함량은 $\mathrm{C} 80+\mathrm{Y} 40$ 시료구가 $73.00 \mathrm{mg} \%$ 로 가장 낮은 함량을 보였고 유자를 가장 많이 섭취한 Y120 시료구 가 $123.11 \mathrm{mg} \%$ 로 가장 높은 함량을 보였다. 총 플라보노이 드 함량은 유자를 섭취하지 않은 $\mathrm{C} 120$ 시료구 $2.29 \mathrm{mg} \%$ 였 고, $\mathrm{C} 80+\mathrm{Y} 40, \mathrm{C} 40+\mathrm{Y} 80, \mathrm{Y} 1203$ 개의 시료구는 각각 2.82 $\mathrm{mg} \%, 3.89 \mathrm{mg} \%, 5.69 \mathrm{mg} \%$ 로 유자 식이 비율에 따라 유의적 으로 증가하였다 $(\mathrm{p}<0.05)$. 이상의 결과로 보아 유자 첨가 사료 보충제 섭취가 갈색거저리의 품질 개선효과와 기능성 향상에 도움을 줄 수 있을 것으로 판단되며 추후 다양한 사료 식이에 따른 기능성 변화에 관한 연구가 이루어져야 할 것으로 보인다.

\section{감사의글}

본 연구는 고흥군농업기술센터의 연구비 지원에 의해 연구되었으며, 이에 감사드립니다.

\section{References}

1. Van Huis A, Van Itterbeeck J, Klunder H, Mertens E,
Halloran A, Muir G, Vantomme P (2013) Edible insects: future prospects for food and feed security. Food and Agriculture Organization of the United Nations, Rome, Italy, $\mathrm{p}$ 171-185

2. Oonincx DG, Van Itterbeeck J, Heetkamp MJ, Vanden Brand H, Van Loon JJ, Van Huis A (2010) An exploration on greenhouse gas and ammonia production by insect species suitable for animal or human consumption. PLoS One, 5, 1-7

3. Kim TH (2018) A study on the consumer's perception of edible insects. MS Thesis, Konkuk University, Korea, p 1-2

4. Bukkens SGF (1997) The nutritional value of edible insects. Ecol Food Nutr, 36, 287-319

5. Jeonnam Agricultural Reserch \& Extension Services (2015) Development of feed additives for poultry with insects. Rural Development Administration, Naju, Korea, p 61-67

6. Yoo SO, Choi YC, Song HS (2011) Breed and utilization of mealworm (Tenebrio molitor). National Academy of Agricultural Science, RDA, Suwon, Korea. p 14-168

7. Yoo JM, Hwang JS, Goo TW, Yun EY (2013) Comparative analysis of nutritional and harmful components in Korean and Chinese mealworms (Tenebrio molitor). J Korean Soc Food Sci Nutr, 42, 249-254

8. Son YJ (2017) Physicochemical characteristics of mealworm (Tenebrio molitor Larvae) and preparation of powders for food material. Ph D Thesis, Seoul National University, Korea, p 1-2

9. Kim SY, Son YJ, Kim SH, Kim AN, Lee GY, Hwang IK (2015) Studies on oxidative stability of Tenebrio molitor larvae during cold storage. Korean J Food Cook Sci, 31, 62-71

10. Lee SH, Lee MS (2017) The study of physiological and antimicrobial activities on the Citrus junos extracts with its textures and skin. J Korea Academia-Industrial Coop Soc, $18,67-74$

11. Moon SH, Ko EY, Awraris DA, Park SW (2014) HPLC method validation of naringin determination in Goheung Yuzu extract as a functional ingredien. J Korean Soc Food Sci Nutr, 43, 1737-1741

12. Kim HY, Kim EH, Kim DH, Oh MJ, Shin TS (2009) The nutritional components of olive flounder (Paralichthys olivaceus) fed diets with Yuza (Citrus junos Sieb ex Tanaka). Kor J Fish Apuat Sci, 42, 215-223 13. Hwang JH, Lee SW, Rha SJ, Jeong DH, Han KH, Shin 
TS (2010) Nutritional characteristics of eels (Auguilla japonica) fed a diet of Yuza (Citrus junos Sieb ex Tanaka). Kor J Fish Apuat Sci, 43, 573-580

14. Jung YH, Kim DH, Kim HY, Shin TS, Oh MJ, Lee JH, Kim JH, Im SY, Kim EH (2010) Effects of diets supplemented with Yuzı Citrus junos Siebold ex Tanaka on disease resistance of olive flounder, Paralichthys olivaceus. J Fish Pathol, 23, 389-398

15. Park NJ, Song C, Kim GH, Cho KY (1994) The evaluating method of the insecticidal activity of three chitin synthesis inhibitors against the yellow mealworm, Tenebrio molitor Linnaeus. Korean J Appl Entomol, 33, 281-285

16. Chung SJ, Lee YH, Chung JH, Lee BR, Han DM (1995) Antifungal effect and activity spectrum of crude antifungal proteins from hemolymph of larvae of Tenebrio molitor in Korea. Korean J Mycol, 23, 232 - 237

17. Kim SY, Park JB, Lee YB, Yoon HJ, Lee KY, Kim NJ (2015) Growth characteristics of mealworm Tenebrio molitor. J Seric Entomol Sci, 53, 1-5

18. AOAC (1995) Official method of analysis of AOAC international. $16^{\text {th }}$ ed, Association of Official Analytical Chemists, Washington, DC, USA, p 69-74

19. KFDA (2007) Test method in general. Int'l Food code(separate volume), Korea Food and Drug Administration, Cheongju, Korea, p 1267

20. Ohara I, Ariyoshi S (1979) Comparison of protein precipitants for the determination of free amino acid in plasma. Agric Biol Chem, 43, 1473-1478

21. Florence CRF, Pascale MG, Jacques, JN (1992) Cystenine as an inhibitor of enzymatic browing.2.kinetic studies. J Agric Food Chem, 40, 2108-2113

22. Chang CC, Yang MH, Wen HM, Chen JC (2002) Estimation of total flavonoid content in propolis by two complementary colorimetric methods. J Food Drug Anal, $10,178-182$
23. Lee JH, Lee JY, Whang JB, Nam JS, Han HK, Kim SM, Im JY, Choi YM, Kim HR, Kim SN (2016) Changes in food composition of Tenebrio molitor by Life Stage. Korean J Food Cook Sci, 32, 656-663

24. Jin TY, Wang MH, Yin Y, Eun JB (2008) Effect of Citrus junos peel on the quality and antioxidant activity of traditional rice wine, Jinyangju. J Korean Soc Food Sci Nutr, 37, 76-82

25. Song EY, Choi YH, Kang KH, Koh JS (1998) Free sugar, organic acid, hesperidin, naringin and inorganic elements changes of Cheju citrus fruits according to harvest date. Korean J Food Sci Technol, 30, 306-312

26. Kim JE, Ji MS (2013) Studies of the grael as medicated diet for the regimenyangsaeng of the elderly. J Oriental Medical Classics, 26, 99-129

27. KFDA (2016) Korean Food Standards Codex Analytical Method, Minstry of Food and Drug Safety, Cheongju, Korea, p 1-7

28. Nishimura T, Kato H (1988) Taste of free amino acids and peptides. Food Rev Int, 4, 175-194

29. Shin JH, Lee SJ, Seo JK, Cheon EW, Sung NJ (2008) Antioxidant activity of hot-water extract from yuza (Citrus junos Sieb. ex Tanaka) peel. J Life Sci, 18, 1745-1751

30. Moon SH, Assefa AD, Ko EY, Park SW (2015) Comparison of flavonoid contents and antioxidant activity of yиzu (Citrus junos Sieb. ex Tanaka) based on harvest time. Kor J Hort Sci Technol, 33, 283-291

31. Voya J, Belinky PA, Aviram M (1997) Antioxidant constituents from licorice roots: Isolation, structure elucidation and antioxidative capacity toward LDL oxidation. Free Radic Biol Med, 23, 302-313

32. Yusof S, Ghazali HM, King GS (1990) Naringin content in local Citrus fruits. Food Chem, 37, 113-121 